\title{
VALORES E SIGNIFICADOS ATRIBUÍDOS AO TERRITÓRIO: PERCEPÇÃO DOS USUÁRIOS SOBRE O BAIRRO CIDADE BAIXA
}

\author{
Michelle Nascimento da Silva ${ }^{1}$ \\ Luciana Inês Gomes Miron²
}

\section{Introdução}

Cada cidade contém traços que lhe são característicos, assim como seus bairros, que são de vital importância para as cidades. Nesse plano, os bairros, com todas suas peculiaridades, contribuem na formação do comportamento da população, por intermédio das regras de conduta nos espaços públicos e privados. Por sua vez, a população usuária experimenta e transforma o espaço circundante, criando um ambiente humanizado pelo seu envolvimento direto, apropriando-se e atribuindo valor e significado às coisas que a cercam.

Ao estudar o funcionamento de alguns bairros americanos, Jacobs (2011) ${ }^{3}$ sustenta que a vitalidade de bairros da cidade advém da sobreposição e entrelaçamento de atividades e que a compreensão das cidades necessita lidar com combinações ou misturas de uso como fenômeno essencial. Essa autora destaca fatores e qualidades urbanos tais como: a variedade de funções e suas inter-relações, a importância de haver intensas atividades nos espaços públicos para maior segurança assim como para definir os padrões espaciais adotados. Para Jacobs (2011), a "vida" estava diretamente associada à diversidade e à multiplicidade de usos das cidades. Nessa perspectiva da diversidade que Jacobs (2011) enaltecia, deve-se compreender em seu aspecto mais abrangente: diversidade de classes sociais e culturais; diversidade e intensidade de usos; diversidade temporal. Entretanto, ao congregarem essa diversidade de usos e de públicos, as cidades, representadas por seus bairros, passam a enfrentar um obstáculo à convivência harmônica em seu território: a divergência entre os diferentes grupos de usuários. Assim, a coexistência de múltiplos usuários pode implicar em conflitos que dificultam ou favorecem a convivência entre os grupos de usuários e seus bairros.

\footnotetext{
${ }^{1}$ Universidade Federal do Rio Grande do Sul, Brasil.

${ }^{2}$ Universidade Federal do Rio Grande do Sul, Brasil

${ }^{3}$ Primeira edição em 1961.
} 
Ainda, Jacobs expõe que o bairro deve ser pensado como órgão com autogestão formal ou informal da coletividade, a própria população local se engaja nas questões de seu bairro e se empenha em torná-lo melhor por meio de ações coletivas ou individuais.

De acordo com De Certeau (1998: 201-202), “espaço é um lugar praticado”. O espaço leva em consideração "vetores de direção, quantidades de velocidade e a variável do tempo". A cidade é caracterizada por suas diversas formas de ocupação e permanência. A cidade, aqui enfocada como território enraizador da diversidade de formas de apropriação e de pertencimento da cidade, bem como de seus bairros, aciona uma gama de valores e significados em seus habitantes. Nesse sentido, Eckert e Rocha (2005: 93) afirmam que:

Conscientemente ou não, através de suas práticas e representações, os habitantes, os citadinos, retomam um ritmo cotidiano outro ao se apropriarem cotidianamente dos territórios dos grandes centros industriais do País. Em face das agitações temporais, eles reatualizam sua vida familiar e reconfiguram redes sociais diversas de pertencimento, atribuindo sentido as suas práticas urbanas.

No tocante à cidade enquanto território, Rogério Haesbaert o entende como definido a partir de relações de poder mediadas pelo espaço: "o território pode ser concebido a partir da imbricação de múltiplas relações de poder, do poder mais material das relações econômico políticas ao poder mais simbólico das relações de ordem mais estritamente cultural" (Haesbaert, 2005: 79). Nesse sentido, pode haver, segundo o autor, a ocorrência tanto de macro como de microterritórios, que podem se configurar a partir de maior ou menor carga funcional e simbólica. Haesbaert afirma que o território, imerso em relações de dominação ou de apropriação sociedade-espaço, "desdobra-se ao longo de um continuum que vai da dominação político-econômica mais "concreta" e "funcional" à apropriação mais subjetiva e/ou "cultural-simbólica" (Haesbaert, 2005: 95-96). Assim sendo, todo território é, em diferentes arranjos, funcional e simbólico, pois as relações de poder têm no espaço um componente indissociável na realização de "funções" e na produção de "significados".

Nesse contexto, o bairro é território que media a rua e a cidade com forma e tamanho, sendo fundamental para a relação do usuário com o meio urbano. $\mathrm{O}$ bairro exibe, antes de tudo, uma configuração física, uma porção urbana que se desenvolve conforme determinados eixos ou direções, em determinada dimensão. Mas, além disso, o bairro é unidade estrutural de natureza espaço-social que representa uma parcela de identidade cultural da cidade. 
As diferentes representações que os usuários têm sobre o ambiente que os cerca implicam nas diferentes relações que podem estabelecer com esse ambiente. Nesse sentido, Ariel Gravano (2003) aborda a noção de bairro, enfatizando seus aspectos simbólicos, considerando as significações, práticas e discursos dos citadinos sobre os problemas urbanos. Esse autor sugere explorar o bairro não apenas no âmbito funcional, mas como espaço simbólico, o qual adquire e constrói valores, e também como referencial de identidades sociais urbanas, o que é chamado por ele de "barrial".

No que se refere à importância da diversidade temporal para a vitalidade da cidade (Jacobs, 2011), mostra-se de grande valia estudar sua evolução urbana em diferentes temporalidades. Segundo Eckert e Rocha (2005), investigar as transformações no meio urbano ao longo do tempo é fundamental. Nesse caminho, Eckert e Rocha (2005: 94) afirmam que:

A cidade é, assim, restituída a sua função primeira: cenário da anamnese de sua comunidade, pois, em seus espaços, emergem as lembranças e signos das representações culturais de seus habitantes, onde o jogo das origens não tem fim e não se submete à ordem e à classificação dos signos.

Cada bairro é portador de suas características peculiares. Bezerra (2005) afirma que o bairro adquire grande relevância na análise da cidade, uma vez que viabiliza o acesso aos acontecimentos sociais locais relacionados à reprodução social e, também, às transformações morfológicas das funções urbanas. Assim, uma vez que o bairro se compõe na limitação espacial do morar, da experiência e das diversas relações que o atravessam, ele se lança como unidade territorial privilegiada para a assimilação e a avaliação das percepções dos usuários sobre as questões urbanas.

Nesse sentido, o bairro Cidade Baixa, em Porto Alegre - RS, é parcela do território urbano portadora de intensa diversidade de usos e usuários, bem como de população local que se sente responsável por seu bairro, logo, possuindo condições para ser considerado, nas palavras de Jacobs (2011), vivo e autogovernado. Como consequência disso, nesse bairro, encontram-se obstáculos a convivência harmônica contínua: de um lado, há os usuários moradores e, de outro, os usuários comerciantes das áreas de lazer e entretenimento noturno e, por consequência, os seus frequentadores.

O presente trabalho busca apresentar a percepção dos grupos de usuários em relação às características do bairro Cidade Baixa. Para tanto, seguir-se-ão dois enfoques que se complementam. O primeiro é constituído pelos usuários, representados na figura 
do Grupo de Trabalho (GT) Cidade Baixa e da associação de moradores, seus valores, conjuntos de significados e suas percepções sobre o bairro; o outro é o território, propriamente dito, e a forma pela qual o bairro dialoga com seus grupos de usuários.

O lócus desta investigação é o bairro Cidade Baixa, o qual possui vida noturna e residencial, caracterizando-se por ser de uso misto, comportando moradores, comerciantes, frequentadores, supermercados, bares, casas noturnas, restaurantes diurnos e noturnos, shopping, bancos, cinema, teatro, escolas, creches, museu e atividades culturais (Silva, 2013). É um bairro que fica próximo ao Centro Histórico da cidade, servindo de bairro de conexão para outros bairros de Porto Alegre. O bairro, que inicialmente se configurava como área rural e de refúgio de escravos (Pesavento, 1999), hoje tem características urbanas, com diversas atividades comerciais, de lazer noturno e serviços. É considerado como um bairro boêmio (Fonseca, 2006), de localização estratégica (Souza, 2008a), que recebe frequentadores de outros bairros da cidade e também de fora de Porto Alegre, estado e país (Silva, 2013).

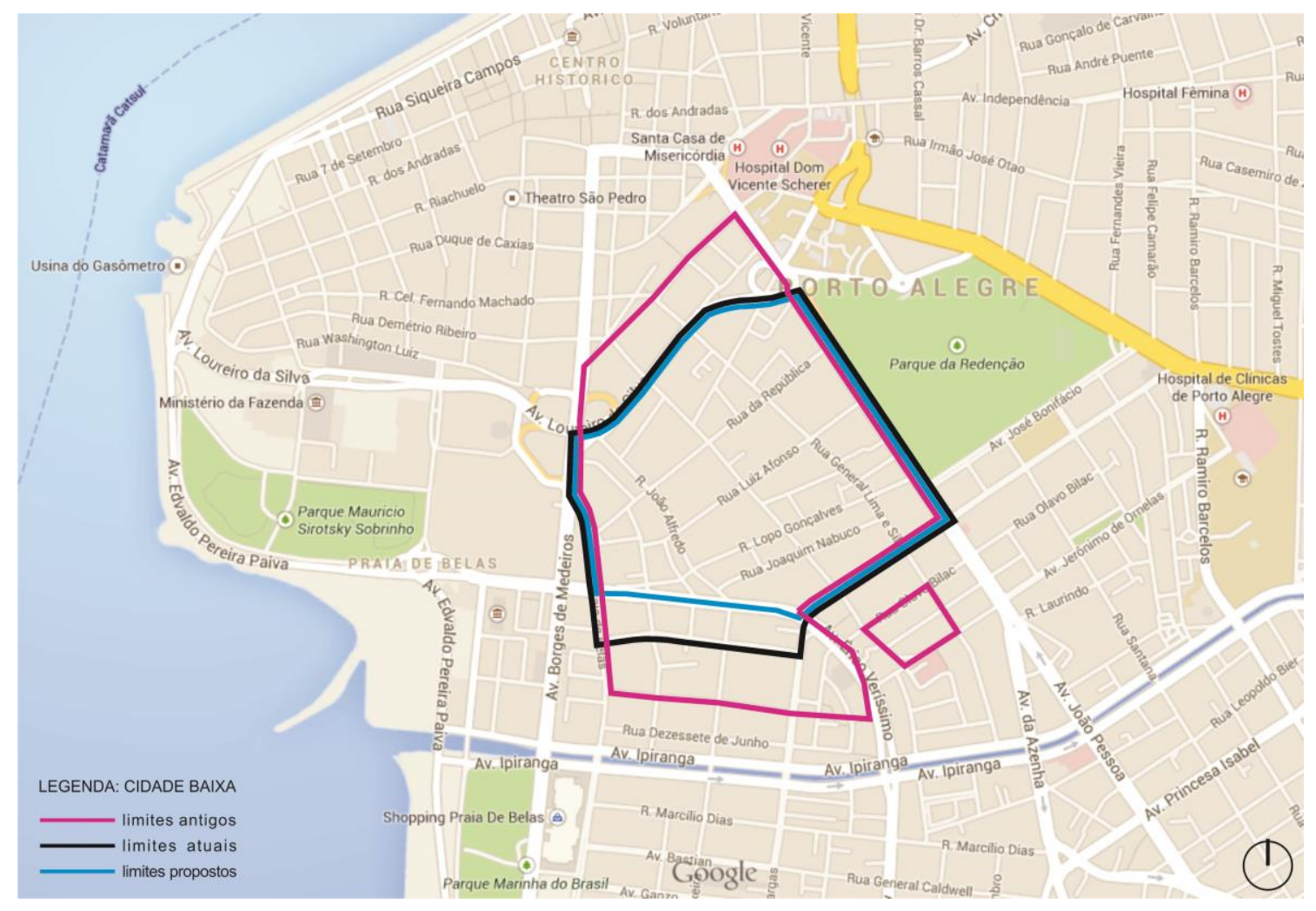

Figura 1 - Limites antigos, atuais e propostos do bairro Cidade Baixa - Porto Alegre. Elaborada a partir do Google Maps, em 19/07/2014. 
A escolha do bairro Cidade Baixa como lócus de pesquisa e estudo se deu pela importância e visibilidade que o bairro tem para a cidade, bem como por sua singularidade em relação aos outros bairros, que é o seu aspecto boêmio e residencial, implicando na coexistência de diferentes grupos de usuários. Por suas características bem marcadas no campo da diversidade e pluralidade de usos sobrepostos, por ser um bairro antigo que atrai o olhar constante da cidade e de seus usuários, que elaboram um imaginário de boemia e cíclicos processos de conflito, negociação e convivência no local. A mídia divulga o bairro, na maior parte de suas matérias, em seus aspectos polêmicos, os periódicos eventos de tensão entre moradores e comerciantes de bares e restaurantes noturnos. Essas situações, muitas vezes, polarizam os moradores de um lado, os quais desejam sossego à noite para descansar e, de outro, os comerciantes, que exercem suas atividades de entretenimento noturno.

O bairro em tela é uma parcela do território urbano portador de diversidade temporal, cultural, de usos e usuários. É, também, palco de constantes conflitos e processos de negociação de convivência decorrentes da intensidade e diversidade de usos e de usuários. Observa-se que, na escala de bairro, coexistem diferentes grupos de pessoas (usuários), o que pode gerar conflito entre os usuários. A presença de manifestações antagônicas entre estes grupos de interesses e valores temporariamente ou pontualmente incompatíveis quanto à apropriação ou a organização de elementos (características) materiais (concretos) ou simbólicos (abstratos) vinculados a seu território resulta em conflitos.

A população estudada foi os grupos de usuários em situação de engajamento com as questões locais do bairro Cidade Baixa. As instâncias de participação e engajamento consideradas foram o Grupo de Trabalho Cidade Baixa e a associação de bairro, pois, devido a este bairro ser palco de conflitos e processos estratégicos cotidianos de negociação de convivência entre seus diferentes grupos de usuários, fez-se necessária, além das associações de bairro existentes, a criação do primeiro Grupo de Trabalho (GT) de Porto Alegre voltado para discutir soluções para os problemas em escala de bairro.

A partir de sua criação, o GT Cidade Baixa realizou diversas reuniões na busca de soluções para os problemas entre moradores e comerciantes. Em 11/04/2012 realizou-se Audiência Pública para debater a situação da vida noturna no bairro Cidade Baixa. Assim, o GT Cidade Baixa, juntamente à comunidade local, readequou os 
horários de funcionamento de estabelecimentos comerciais noturnos criando o Decreto $17.766^{4}$, de 2 de maio de 2012, que estabelece o horário de funcionamento das atividades de bar, restaurante, café e lancheiria no bairro Cidade Baixa. E ainda, desencadeou um fenômeno de engajamento dos grupos de usuários (moradores e comerciantes) com as questões de seu bairro. Esses grupos passaram, então, a buscar diversificadas soluções para melhorar o bairro e a convivência entre os diferentes usuários.

Outro encaminhamento importante do GT Cidade baixa para solucionar os barulhos advindos a vida noturna foi a proposta que estabeleceu três níveis de polarização para o bairro Cidade Baixa, onde os estabelecimentos de atividade noturna podem funcionar. O primeiro permitiria concentração elevada de atividades noturnas. $\mathrm{O}$ segundo flexibilizaria o funcionamento de estabelecimentos à noite em nível um pouco menos elevado do que o primeiro. Por fim, o terceiro ofereceria uma concentração de bares mais branda.

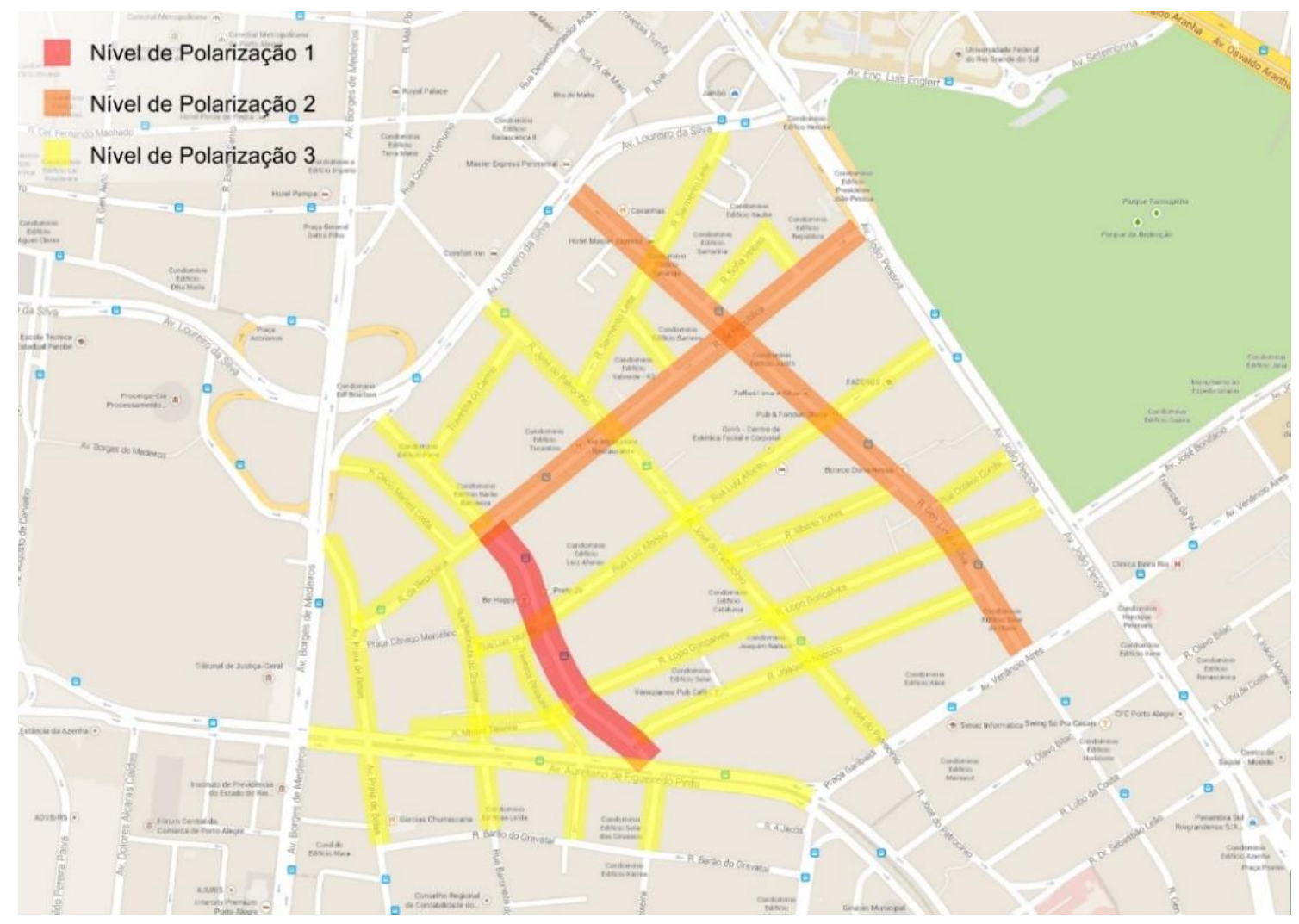

Figura 2 - Níveis de polarização no bairro Cidade Baixa. Elaborado a partir do Google Maps.

\footnotetext{
${ }^{4}$ Após 90 dias, o Decreto 17.766/12 (de caráter experimental) cedeu lugar ao decreto 17.902/12 (caráter definitivo).
} 
Os três níveis de polarização são: Nível de polarização 1) Rua João Alfredo, entre a rua da República e a Av. Aureliano de Figueiredo Pinto; nível de polarização 2) Rua da República, entre a João Alfredo e a Av. João Pessoa e Rua General Lima e Silva, entre a Av. Venâncio Aires e a Av. Loureiro da Silva; e nível de polarização 3) as demais vias do bairro Cidade Baixa (Decreto $N^{\circ}$ 17.767, de 2 de maio de 2012).

\section{Do território à simbolicidade de lo barrial}

A expressão território deve ser lembrada como territórios que existem e são construídos e desconstruídos nas mais diversas escalas, temporais e espaciais. Território é espaço definido e delimitado por e a partir de relações de poder, quer seja entre Estados, entre movimentos sociais, pequenas comunidades, famílias ou trabalhadores, e que mantenha certa continuidade quanto às características dos recursos naturais, culturais, econômicos e sociais (Souza, 2008b).

Para o Rogério Haesbaert, é possível agrupar as várias concepções de território em três diferentes enfoques: político ou jurídico-político, cultural ou simbólico-cultural; econômica. Ao que se refere ao aspecto cultural ou simbólico-cultural, segundo Haesbaert (2005: 91), o território pode ser compreendido da seguinte forma:

Cultural (muitas vezes culturalista) ou simbólico-cultural; aquela que prioriza a dimensão simbólica e mais subjetiva, em que o território é visto, sobretudo, como o produto da apropriação/valorização simbólica de um grupo em relação ao seu espaço vivido.

Nesse sentido, os territórios são construídos socialmente. Ou seja, é reflexo, basicamente, de toda a produção advinda das relações entre as pessoas, bem como das relações que elas estabelecem com o espaço. O território é entendido em sentido mais subjetivo e afetivo, como espaço físico delimitado e apropriado por grupo específico, com características culturais também específicas, ligado às relações mais funcionais e culturais que molduram a territorialidade do grupo, determinando, assim, o valor de uso dos espaços como parte singular do espaço maior, ou mesmo de outro território.

A concepção de territorialidade está ligada a ordens de subjetivação em relação ao espaço, envolvendo condutas, representações e sentimentos de pertencimento expressos individual e coletivamente. De acordo com Roncayolo (1990), a territorialidade é fenômeno cultural e multidimensional, fundamentalmente coletivo, contendo também características psicológicas, econômicas e geográficas. Reporta-se a 
formas de inserção nos espaços, caracterizando-os como regiões de apropriação. Em sua prática, “apropriação, poder e representações se combinam” (Roncayolo, 1990: 189). É possível constatar-se sentimentos de apego, duradouros a determinados lugares, ou ainda, apresentarem-se formas de organização social e simbólica que podem ser reproduzidas por seus atores ao mudarem de espaço.

Para Raffestin (1993), a territorialidade comporta aspectos inerentes ao território, seu conteúdo, sua materialidade e imaterialidade. A territorialidade consistiria na maneira pela qual o homem estabelece seu vínculo com o meio onde vive. Neste sentido, o território abarca a ordem de subjetividade coletiva que torna possível as ações territoriais de resistência para os grupos sociais em oposição as imposições realizadas por diferentes seguimentos econômico, político e sócio culturais.

A territorialização, para Haesbaert (2007), consiste em estabelecer intercessões espaciais capazes de propiciar eficazmente o poder sobre a reprodução como grupos sociais, devendo, no entanto, levar em consideração a multiplicidade geográfica, uma vez que tais intercessões são essencialmente reflexos de aspectos culturais e de identidade. A territorialidade, mesmo sendo objeto de poder, é também a intercessão simbólica que a as características distintas do território permitem.

Considerando os aspectos culturais e de identidade mencionados no parágrafo anterior, Souza (2008b: 84) traz outra contribuição importante ao que se refere à ocupação do território que, segundo o autor:

(...) é vista como algo gerador de raízes e identidade, ou seja, um grupo não pode mais ser compreendido sem o seu território, no sentido de que a identidade sociocultural das pessoas estaria inarredavelmente ligada aos atributos do espaço concreto (natureza, patrimônio arquitetônico, paisagem).

O sentido de identidade no território referido estabelece elo com a territorialidade, visto que ela é compreendida, segundo Raffestim (1993), como algo de essência multidimensional e intrínseca à vida em sociedade e, por essa razão, contrai valor específico. Assim, a origem da concepção de identidade associa-se à discussão a respeito do território.

A identidade, segundo Castells (2003), consiste em um dos elementos mais relevantes na composição do espaço. $\mathrm{O}$ espaço, assim, se revela como necessidade básica para que os grupos sociais tenham condições de desenvolver suas relações e consolidarem suas identidades. Nesta direção, a identidade, a partir dessas inferências, 
apresenta-se como modo de distinção do eu com o outro, elaborada ante atributos culturais peculiares, ou, além disso, embasada em uma gama de atributos culturais interrelacionados.

Castells (2003) trata também sobre a inter-relação existente na formação das identidades, pois os indivíduos são cercados por diversas identidades e atributos culturais, ora um prevalecendo sobre o outro, o que resulta na geração de tensões e conflitos. Nesta direção, Castells (2003) compreende que toda identidade se constrói socialmente, e seus significados e símbolos são definidos através dos próprios atores que as constroem, isto é, no processo de construção de identidades são transmitidos elementos históricos, geográficos, biológicos, econômicos e institucionais dos mesmos indivíduos que realizam a construção. Esses processos são responsáveis por conferir forma e origem para a construção de identidades dinâmicas.

Segundo Hall (2006), é a partir do confronto de poder motivado pelo processo relacional com o outro que as identidades estão, gradativamente, fragmentando-se. Neste sentido, Hall demonstra que as identidades modernas são estabelecidas historicamente e não biologicamente, uma vez que as identidades "costuram o sujeito à estrutura" (Hall, 2006: 11), razão pela qual ele infere que as identidades são sempre contextuais e acompanham as dinâmicas sociais. Sobre isso, o autor aponta:

A identidade plenamente unificada, completa, segura e coerente é uma fantasia. Ao invés disso, a medida em que os sistemas de significações e representações culturais se multiplicam, somos confrontados por uma multiplicidade desconcertante e cambiante de identidades possíveis, com cada uma das quais poderíamos nos identificar - ao menos temporariamente. (Hall, 2006: 13)

Hall (2006) acredita que, na contemporaneidade, deveríamos falar em identificação e não em identidade, já que a identidade é algo formado ao longo do tempo, permeando processos inconscientes e conscientes, e não algo inato, que já está presente nos indivíduos desde o momento de sua gênese. Por isso, esse autor também vai justificar as análises espaciais e temporais para a compreensão das identidades. Uma das principais leituras que se deve fazer dos processos e construções identitárias é a que recobre a apreensão do espaço e do tempo dos grupos sociais nos contextos atuais. Em alguma medida, essa apreensão do espaço se aproxima da percepção do espaço urbano pelo usuário. 
Haesbaert (1997) aponta que a identidade no pensamento moderno se estrutura a partir de pessoas e símbolos que circundam elementos aglutinadores, é o agrupamento do que é reconhecido enquanto semelhante ante da multiplicidade de sujeitos e objetos da atualidade. Haesbaert sublinha a importância de se considerar as bases materiais e territoriais nos processos de formação de identidades, além dos aspectos simbólicos. O conceito de identidade é tratado como condição que faz referência às coisas e às pessoas a partir das relações de semelhanças, igualdades e diferenças. Nessa perspectiva, as identidades agregariam uma rede de relacionamentos com o outro, com o externo, sendo também dotadas de materialidade. Pode-se inferir que o território se define pela ideia de relação das pessoas com seus territórios. Ou ainda, de acordo com Raffestim (1993), o território se forma a partir do espaço. Trata-se da apropriação do espaço que poderá ser concreta ou abstrata (por exemplo, uma representação), visível ou invisível e é resultado de ação empreendida por diversos atores.

Ainda de acordo com o autor, as identidades sociais são compreendidas como identidades territoriais quando um dos elementos centrais para a construção das identidades passa pelo território. Segundo esse autor, as identidades têm seus signos no espaço simbólico, o qual é social e historicamente construído. De tal modo, o espaço consistiria em referência para a formação das identidades (Haesbaert et al., 2007). Em suas palavras, aponta que "a construção do imaginário de identidade envolve, portanto uma escolha entre múltiplos eventos e lugares no passado, daqueles capazes de fazer sentido na atualidade" (2007: 37). Em vista disso, as identidades com seu caráter múltiplo são sempre concebidas em relação ao passado, ao tempo, e também em relação ao presente e ao espaço.

Considerando a forte associação de características abstratas aos conceitos de território, territorialidade e identidade, e que esta pesquisa está associada à percepção de grupos de usuários sobre as catacterísticas de seu território local, onde considera-se seu engajamento com o meio, bem como, o desenvolvimento de sua identidade, sublinha-se a pertinência de abordar os aspectos conceituais do bairro. Os bairros, segundo Gonçalves (1988), são mais valorizados quanto à intensidade da significação e quanto à qualidade de utilização e de apropriação simbólica, sempre que sejam especificados, quer por determinado tipo de população, quer por função particular, quer ainda pela conjunção destas duas características. O bairro caracteriza-se como sendo o lugar onde 
está presente predominantemente, embora não exclusivamente, uma população ou uma função particular.

Antônio Candido Mello Souza (1987: 57-65) afirma sobre o bairro o seguinte:

(...) além de determinado território, o bairro se caracteriza por um segundo elemento, o "sentimento de localidade" existente nos seus moradores, e cuja formação depende não apenas da posição geográfica, mas também do intercâmbio entre as famílias e as pessoas, vestindo por assim dizer o esqueleto topográfico: - O que é bairro? - perguntei certa vez a um velho caipira, cuja resposta pronta exprime numa frase o que se vem expondo aqui: - Bairro é uma naçãozinha. - Entenda-se: a porção de terra a que os moradores têm consciência de pertencer, formando uma certa unidade diferente das outras.

Em seu trabalho sobre a memória de velhos moradores de São Paulo, Bosi (2009) constata que os caminhos percorridos pelos moradores do bairro, e seus marcos de orientação no espaço, estão eivados de significados. "O bairro é uma totalidade estruturada, comum a todos, que se vai percebendo pouco a pouco, e que nos faz um sentido de identidade” (:147). Para a autora, esse espaço urbano é um “(...) lugar nosso, e um lugar nosso deve ter (...) fechamento e proximidade de elementos, deve ser mais denso que seu entorno e permitir a dialética da partida e do retorno" (: 147).

A prática cultural pode ser compreendida como forma de expressão da territorialidade. Nesta direção, Mayol (1998) refere-se ao bairro como o lugar pelo qual o morador se apropria quando transgride o âmbito privado residencial. O mesmo se dá, segundo ele, "mediante a repetição do engajamento do corpo do usuário no espaço público" (: 42). Ainda, ao discutir sobre o bairro, Mayol enfatiza a prática cultural como decisiva para a identidade de grupo, bem como que o bairro é, para o usuário, parcela conhecida do espaço urbano na qual ele se sente reconhecido. A prática cultural é concebida por este autor como: "o sistema de valores subjacentes que estruturam as tomadas de atitudes fundamentais da vida cotidiana, que passam despercebidos à consciência dos sujeitos, mas são decisivos para sua identidade individual e de grupo" (Mayol, 1998: 43).

Semelhante à visão simbólico-cultural de Haesbaert (2005) sobre o território, Ariel Gravano (2003), entende o bairro como espaço simbólico-ideológico que forma parte do imaginário urbano em três dimensões: a) componente da reprodução material da sociedade e espaço físico que faz parte da cidade; b) como identidade social atribuída pelos atores sociais; e c) como conjunto de valores condensados e compartilhados socialmente. 
Sobre o conjunto de valores referidos no parágrafo anterior, Gravano (2003) o chama de simbolicidade de lo barrial. Para esse autor (: 60 -61), no conjunto de variáveis associadas à capacidade de lo barrial para ser representativo ou substituto de valores, devemos incluir, então, o que - para continuar com os neologismos poderíamos chamar de simbolicidade de lo barrial. Os valores assim construídos pelos atores nessa situação têm no bairro sua referência socioespacial que se reflete na produção de sentido do imaginário urbano, com representações não coincidentes com as marcas físicas, e até mesmo contraditórias. Entre os mais recorrentes está a emergência como símbolo das bases populares, de coesão e integração. O bairro mesmo aparece como valor principal quando serve de eixo de distinção acima dos outros signos atributivos. Essa transcendência simbólica de lo barrial, como valor em si mesmo compartilhado por distintos grupos sociais, poderia planejar a possibilidade de constituir-se em cultura, entendida como sistema de representações e práticas compartilhadas socialmente em torno de valores distintos; potencialidade a qual vamos chamar de culturicidade de lo barrial.

Com a definição preconizada por Gravano (2005), o bairro, como espaço de construção simbólica, presume a disputa de significados e significações, bem como a lide contínua pela imposição de sentidos. Essas visões sobre o conceito de bairro têm importante influência na consciência identitária e de localidade do morador de parcelas do tecido urbano predominantemente mais antigos. Associado ao conceito de bairro, o conceito de lo barrial, empregado por Gravano (2003) em sua pesquisa etnográfica em alguns bairros de Buenos Aires, vem a contribuir nos estudos referentes aos bairros.

Segundo Gravano (2003), o entendimento de lo barrial considera a dimensão material, cujo referente se localiza no espaço físico da cidade, conhecido como bairro; bem como a dimensão simbólica, marcada por um grupo de valores morais comuns pelas pessoas ao longo de suas experiências acumuladas no espaço de moradia. Tais valores surgem no discurso dos moradores por meio de um conjunto de expressões e adjetivos que sugerem idealismo das relações sociais a serem estabelecidas e conservadas no bairro onde se aspira viver.

Gravano (2003) apresenta três variáveis que caracterizam a definição de barrial: a) identidade social: formada quando os atores sociais admitem identificar-se ou pertencer a diferentes bairros como meio de distinguir-se e sugestionar os 
comportamentos coletivos; b) segmentalidade: peculiaridade que possui os bairros de abarcar no seu interior campos com identidades heterogêneas, sem abandonar a relação de conexão dentro da própria unidade; c) tipicidade: imputação de classificações gerais, dicotômicas e de senso comum a respeito de algumas identidades barriais, constituindo relação direta entre a representação negativa ou positiva do bairro com a conduta de seus moradores.

Considerando que a dimensão simbólica do bairro é marcada por valores comuns entre as pessoas (Gravano, 2003), bem como pela prática cultural (Mayol, 1998), é possível que, a partir da análise de conceitos de bairro, a relação com valores possa ser incrementada. Nesse sentido, pessoas que moram no mesmo bairro podem apresentar conjunto de valores e significações em comum devido a compartilharem a mesma parcela do território urbano. Por sua vez, cada bairro contém características peculiares que o diferencia dos demais.

\section{O bairro Cidade Baixa: um bairro boêmio em Porto Alegre}

De acordo com Pesavento (1999), a cidade de Porto Alegre teve sua formação iniciada na segunda metade do século XVIII com o surgimento do primeiro povoado açoriano situado às margens do Guaíba. Em 1778, foram construídas fortificações ao redor da cidade como medida protetiva às ameaças castelhanas. Elas consistiam em "altas cercas de madeira circundadas por um fosso ou valo" (Pesavento, 1999: 33), e foram demolidas em 1845 ao fim da Revolução Farroupilha.

O setor "intramuros" era conhecido como Cidade Alta. Em contraposição a essa que era a "verdadeira cidade" (Pesavento, 1999: 33), na área "extramuros", localizada ao longo do sul da colina da rua Duque de Caxias (Franco, 1998), surgiu e se desenvolveu a Cidade Baixa. Foi após a remoção das fortificações que se deu início à “conformação efetiva do bairro" (Claro, 1997: 5) com o povoamento viabilizado a partir da Ponte de Pedra sobre o Arroio Dilúvio (Franco, 1998).

A circunscrição do território conhecido como Cidade Baixa possuiu diversas denominações anteriores: Arraial da Baronesa, Emboscadas, Areal da Baronesa e Ilhota. O Arraial da Baronesa remetia-se à ampla extensão de terras pertencentes à Baronesa do Gravataí, onde se situava sua chácara, bem como pequenas propriedades rurais à base de mão de obra escrava (Claro, 1997). Sua mansão era onde atualmente está a Fundação 
Pão dos Pobres. Naquela época, Emboscadas foi a denominação do extenso perímetro constituído de mata densa pertencente ao Arraial da Baronesa, que abrigava os escravos que fugiam de seus senhores (Sapiezinkas, 2004).

Posteriormente, o bairro Cidade Baixa, passou a se chamar de Areal da Baronesa em alusão a areia vermelha do local. A Baronesa do Gravataí, após um incêndio, loteou e vendeu sua vasta propriedade de terras que, a partir de então, passou a ser ocupada por escravos alforriados e famílias de origem italiana (Menegotto, 2001). Segundo Pesavento (1999: 12), "nenhum melhoramento urbano recebeu, e os terrenos baixos, no desembocadouro do riacho, alagadiços e expostos a frequentes enchentes, fizeram da área um reduto da mais extrema pobreza, com uma população majoritariamente negra". Após a abolição da escravatura em 1884, “os escravos libertos deram origem aos primeiros núcleos habitacionais, os quais formaram verdadeiros bairros negros, próximos às propriedades de origem" (Claro, 1997).

Parte desse território também foi conhecida como Ilhota após intervenções realizadas, em 1905, no fluxo do "Riachinho" para aumentar sua vazão (passando a ser chamado de Arroio Dilúvio) que passava pela região. Neste sentido, a área de uma pequena ilha (Ilhota) se formou a partir destas modificações (Zamboni, 2009). Segundo Pesavento (1999: 12), “além de pedaço de terra isolado pelas águas, era também um espaço de isolamento social e exclusão". O local se caracterizava por ser área com riscos de inundações, insalubre e ocupada por moradores bastante pobres.

Após a instalação da República Velha (1889-1930), a cidade de Porto Alegre e, extensivamente a Cidade Baixa, iniciou seu período desenvolvimentista de natureza positivista (Pesavento, 1999), no qual se deu ênfase ao fomento da indústria e da renovação urbana. Ao longo do desenvolvimento e expansão do centro da cidade, a Ilhota e Areal da Baronesa passaram por processo de favelização nas primeiras décadas do século XX (Claro, 1997).

A partir da primeira metade do século XX, a população local aumentou sensivelmente em decorrência da supressão das poucas chácaras existentes e passam a compor o bairro indústrias, cinemas e a sede paroquial (Igreja Sagrada Família). O bairro passou por diversas intervenções urbanísticas, pois contava com localização estratégica e privilegiada. Com a expansão urbana, a Cidade Baixa servia de meio de conexão com os demais lugares da cidade, especialmente a Zona Sul, pelo caminho da Azenha (Franco, 1998). Naquele período, foi elaborado o Plano de Melhoramentos com 
a finalidade de ligar o centro aos bairros. Na implantação do Estado Novo (1937-1945), fizeram-se as maiores obras viárias em Porto Alegre.

A intervenção urbanística mais expressiva ocorreu na segunda metade do século XX. Tratou-se da implantação do Projeto Renascença, executado pelo poder público municipal de Porto Alegre entre 1975 e 1979 com a finalidade de melhorar a infraestrutura urbana (Souza, 2008a). Uma das ações mais impactantes do projeto foi a partir de 1976, quando a Ilhota deixou de existir e grande parte de seus antigos ocupantes passaram a residir na Restinga. É possível verificar esta percepção pelos exmoradores pelo trecho da resenha sobre a etnobiografia $O$ Mestre Borel: ancestralidade negra em Porto Alegre escrita por Santiago Millan:

O Mestre Borel na Restinga anuncia que o espaço primário foi reformado, sendo desocupado física e parcialmente pelos negros e produzindo processos de migração intra-urbana rumo à periferia da cidade, a comunidade que migra se encontra em lugares diferentes da cidade mantendo relações aqui e lá, ampliando o espaço da identidade compartilhada (Millan, 2013).

Nos anos de 1980, a área oficial do bairro Cidade Baixa era contornada pelas perimetrais com corredores de ônibus que garantiam o deslocamento da população do centro para outros bairros (Jardim, 1991). O bairro adquire novo formado e passa a acolher moradores de classe média.

A partir dos anos de 1990, surgem movimentos espontâneos de revitalização cultural. A decadência do bairro Bom Fim, que foi espaço de lazer noturno de Porto Alegre, na década de 1980, atraiu investimentos para a Cidade Baixa (Jardim, 1991: $60)$.

O bairro Cidade Baixa, ao longo do tempo, foi permeado por diversos públicos, os quais se apropriavam deste espaço, também, como território boêmio. Nas palavras de Cornélia Eckert (2005: 5):

O bairro Cidade Baixa, evitado no início do século pela sua identificação com comunidades de descendência africana, mais tarde transferidas para a periferia, passou a abrigar edifícios residenciais para segmentos médios e uma importante vida noturna (bares e restaurantes).

No início da década de 1990, "surgem movimentos espontâneos de revitalização cultural no bairro" (Figueiredo, 2008). Dados os diferenciais entre esse bairro e os demais da cidade de Porto Alegre, diversos estudos na área de Ciências Sociais 
elegeram o bairro Cidade Baixa para analisar seus diversos grupos sociais, bem como suas respectivas formas de ocupação do território.

Nesta direção, Silva (2013) mostra o bairro Cidade Baixa a partir de abordagem etnográfica, na qual evidencia formas da dinâmica do lugar, e como seus diversos atores exercem suas práticas no cotidiano, de modo a assinalarem contextos voltados aos sentidos de identidade e pertença que têm com bairro e à sociabilidade. Silva (2013) exibe cenários urbanos e grupo de usuários apresentando o bairro como lócus vivenciado a partir de um prisma que o diferencia no conjunto de sua urbe: a diversidade cultural. Podendo-se inferir, a partir disso, que o bairro Cidade Baixa é permeado por intensa diversidade de usos e usuários.

Vedana (2004) aponta em sua pesquisa etnográfica, voltada para as práticas cotidianas e formas de sociabilidade e performance de "fregueses e feirantes", a existência de uma feira livre localizada no Largo Zumbi dos Palmares no bairro Cidade Baixa. Sapiezinskas (2004) ocupou-se de avaliar etnograficamente a percepção de moradores de 15 casas "em fita" situadas na Travessa dos Venezianos, tombadas pelo patrimônio histórico, em relação as políticas públicas de tombamento e preservação de bens imóveis históricos, bem como o impacto gerado em suas vidas cotidianas. Por sua vez, Marques (2006) elege outro grupo de moradores do bairro em sua etnografia, qual seja: os que se reconhecem enquanto remanescentes (quilombo) do Areal da Baronesa e vivem na Avenida Luiz Guaranha (que corresponde atualmente ao bairro Menino Deus).

Cogo (1999) e Figueiredo (2008) elegem como objeto de pesquisa o Centro Comercial Nova Olaria, espaço que congrega uma gama de diferentes tipos de frequentadores. Enquanto Cogo (1999) faz abordagem sociológica sobre a oferta e o consumo de lazer junto aos "grupos sociais mais favorecidos" que frequentam este espaço comercial; Figueiredo (2008) avalia etnograficamente a construção de representações sociais, identificando os "bons frequentadores", os "maus frequentadores" e os "frequentadores invisíveis, quais sejam: os grupos cult e homossexual (clientes, intelectuais, sofisticados, seguidores das normas de conduta); o jovem gay (não-clientes, estigmatizados, pobres, não seguem normas de conduta); e idosos (com visibilidade social imperceptível).

Germano (1999) e Frydberg (2007) tecem considerações sobre o universo boêmio antigo no bairro Cidade Baixa. Naqueles trabalhos, pode-se observar que o bairro inicia seu referencial boêmio bem antes das transformações urbanas realizadas no 
local. Germano (1999), ao abordar historicamente alguns aspectos da construção da identidade negra em Porto Alegre, pelo carnaval de rua nas décadas de 30 e 40, aponta a Cidade Baixa (Areal da Baronesa e Ilhota) como um dos principais lugares onde o carnaval consolidava a identidade negra, bem como espaço boêmio e de sociabilidades negras. Já Frydberg (2007) buscou capturar os significados das narrativas do cantor e compositor Lupicínio Rodrigues, nas quais foi possível descortinar os lugares que frequentou, sobretudo a Ilhota, onde nasceu e mantinha, com outros músicos da época, uma vida boêmia.

Fonseca (2006) retratada a ocupação do Cidade Baixa por estabelecimentos de entretenimento e lazer noturno em três períodos:

\footnotetext{
O primeiro estende-se da década de 40 ao final da década de 80, e corresponde aos primeiros bares. $\mathrm{O}$ segundo agrega a esses bares já existentes aqueles que surgiram na década de 90, enquanto o terceiro e último período acrescenta aos bares já existentes, aqueles que surgiram no ano 2000 até 2005. (Fonseca, 2006: 110).
}

Fonseca (2006) apresenta a evolução das atividades voltadas para a vida noturna no bairro, sendo que, entre as décadas de 40 e 80, foram pouco expressivas. Já a partir da década de 90 até os anos 2000, a quantidade se mostra superior, adquirindo maior fôlego entre os anos 2000 e 2005. Hoje o bairro comta com 202 estabelecimentos voltados para o público boêmio, os quais fazem alusão à boemia do passado, porém possuem vertente mais comercial. A boêmia parece desempenhar papel de qualificador do bairro para fins de consumo na área de gastronomia e entretenimento noturno.

Segundo Figueiredo (2008), a tradição boêmia do bairro Cidade Baixa vem desde as primeiras décadas do século XX. O imaginário boêmio até a década de 1940, em Porto Alegre, desvela-se a partir da vida noturna existente na Ilhota. "A Ilhota era um bairro boêmio com muitos bares, muitos músicos e seresteiros (Fridberg, 2007: 19). Neste cenário, surge o expoente da boemia local, Lupicínio Rodrigues:

A música fazia parte de sua vida (de Lupicínio) de forma quase que inata, uma vez que, sem esforço, o pequeno Lupi utilizava este código para se comunicar. (...) Esta facilidade de comunicação através da música fez com que Lupi se aproximasse dos boêmios e da boemia da região onde morava. Esta aptidão que o jovem Lupi apresentava para música foi logo identificada pelos músicos e boêmios da Ilhota, que fizeram dele cantor do grupo musical do bairro. A inclinação musical de Lupicínio Rodrigues se deu na noite entre notívagos e músicos de bares. (Fridberg, 2007: 19-20). 
O trecho acima, ao mostrar como se deu o início da carreira de Lupicínio Rodrigues, demonstra também a existência de vida noturna pulsante na Cidade Baixa de antigamente. O Areal da Baronesa e Ilhota (atual Cidade Baixa) eram compreendidas como espaço boêmio e carnavalesco, bem como portadoras das sociabilidades da população negra (Germano, 1999). Entretanto, a vida noturna, boêmia era ambientada em contexto bastante distinto da existente atualmente, como é possível depreender a seguir:

\begin{abstract}
Entramos, portanto, no passado do Areal e da Ilhota: suas ruas, seus casebres e cortiços, seus botecos, suas casas de batuque, suas rodas de samba, seus carnavais, seus blocos e cordões são inseparáveis do Riacho, também denominado Riachinho, que definia naquela época grande parte da fisionomia dos territórios. Os matagais, as árvores nativas e frutíferas, os arbustos, o aspecto praiano, a areia, a terra molhada, o coaxar dos sapos, as moscas, o barro nos dias de chuva, a poeira nos dias secos, o som das águas correndo até desembocarem no Guaíba, as pequenas embarcações, as pontes precariamente construídas que ligavam o Areal e a Ilhota ao resto da cidade eram vivencias e cotidianamente experienciadas por seus moradores.

(...) Tanto o Areal da Baronesa quanto a Ilhota foram circundadas pelo Riachinho, que marcou significativamente o cotidiano desses espaços, tanto por suas frequentes inundações quanto pelas experiências vividas cotidianamente pela população que os habitou. O Riacho criou fronteiras físicas no interior da cidade, mas também simbólicas, associando os moradores de suas cercanias a uma população pobre, negra e marginalizada. Essa população compunha-se, em sua maioria, por biscateiros, empregadas domésticas, lavadeiras, cozinheiras, prostitutas, desempregados, operários, portuários, pequenos funcionários públicos, praças e graduados da Brigada Militar (Germano, 1999: 167-168).
\end{abstract}

Mesmo com o hiato temporal existente entre o surgimento de seu mito boêmio (até a década de 1940) e seu resgate (década de 1990), a história do bairro boêmio permaneceu ativa no imaginário do porto-alegrense. O ambiente boêmio da primeira metade do século XX, embalados pelo cotidiano de Lupicínio Rodrigues e tantos outros músicos da Ilhota é interrompido, cedendo lugar para o ambiente predominantemente residencial. Essa primeira fase boêmia deu-se predominantemente na Ilhota e mediações (Areal da Baronesa) e imersa em relações contraditórias, uma vez que era local boêmio e também às margens da cidade formal. Sobre a Ilhota, Souza (2008a: 41) diz:

A sua relação com a cidade formal era bastante contraditória. Por um lado, a Ilhota era identificada como um local tradicional de cultura popular através do samba e do carnaval (berço do compositor Lupicínio Rodrigues, por exemplo); por outro, era associada à marginalidade e ao crime. De qualquer forma, a Ilhota estava fora de lugar para a maioria de seus contemporâneos porto-alegrenses. 
Após algumas décadas, por volta de 1990, o bairro volta a ser cenário da vida noturna em Porto Alegre. O bairro adquire maior superlatividade com a decadência da vida noturna existente no bairro Bom Fim, pois passa a receber também o público vindo de lá. O potencial histórico, bem como sua boa localização, fez do bairro área fértil para os empreendimentos voltados para o setor de gastronomia, lazer e entretenimento, especialmente o noturno. A reinauguração da vida noturna na Cidade Baixa se dá a partir da revitalização do bairro na década de 1990, atraindo diversos investimentos. O Cine Guion e o bar Opinião, segundo Mendonça (2004), foram os seus macro-atratores.

Jardim (1991) e Fonseca (2006), delimitam seus estudos ao universo boêmio recente do bairro Cidade Baixa. Jardim (1991) elabora uma etnografia que estuda o público masculino de classes populares a partir de sua ocupação junto aos bares do bairro. Segundo Jardim (1991: 2), "em um bairro ocupado por diferentes grupos sociais, esses homens se encontram auto-segregados". Por sua vez, Fonseca (2006), em abordagem sociológica, procurou investigar as causas que provocavam a migração de frequentadores da vida noturna no bairro Moinhos de Vento para a Cidade Baixa, concluindo que a principal razão dessas migrações era a diversidade existente no bairro Cidade Baixa.

A Cidade Baixa, com forte concentração de bares e casa noturnas, caracteriza-se, atualmente, por ser uma das principais opções de entretenimento e lazer noturno para diversos grupos de usuários na cidade de Porto Alegre - RS. Verifica-se a crescente articulação de símbolos e práticas culturais por intermédio de atividades comerciais voltadas para a vida noturna do bairro. Presente no imaginário das pessoas como bairro boêmio (Jardim, 1999; Germano, 1999; Marques, 2006; Fonseca, 2006; Fridberg, 2007), o bairro congrega grande fluxo de público, qual seja: moradores, habitués e turistas. Nas palavras de Fonseca (2006: 15) podemos ilustrar algumas especificidades do bairro: “(...) uma área boêmia antiga, a Cidade Baixa, com importante presença no panorama cultural da cidade, frequentado por uma gama bastante diversa de 'tipos culturais', como estudantes universitários, artistas, intelectuais, profissionais liberais, etc."

Atualmente, considerado o prolongamento imediato do centro de Porto Alegre (Barcellos, 2004), compreendendo uma área total de $0,93 \mathrm{~km}^{2}$, o bairro Cidade Baixa, segundo Claro (1997), está localizado na porção central do município de Porto Alegre. Os limites do bairro, definidos de acordo com a Lei 2022 de 7 de dezembro de 1959, e 
alterados pela Lei 4685 de 21 de dezembro de 1979 são os seguintes: Av. Praia de Belas até a Rua Barão do Gravataí; desta até seu encontro coma Av. Getúlio Vargas; por esta via, sentido sul-norte, até a Av. Venâncio Aires; desta até a Av. João Pessoa e por esta até a Av. Perimetral, até encontrar a convergência da Av. Borges de Medeiros com Av. Praia de Belas. Cabe ainda salientar que o bairro em tela faz divisa com seis bairros da Região Centro, são eles: Centro Histórico, Farroupilha, Santana, Azenha, Menino Deus e Praia de Belas.

Segundo Anteprojeto de Lei de 11/11/2013, o qual dispõe sobre a criação, extinção, delimitação e denominação de bairros de Porto Alegre, os novos limites do bairro Cidade Baixa seriam: ponto inicial e final - encontro da Av. Praia de Belas com Av. Aureliano de Figueiredo Pinto. Desse ponto segue pela Avenida Aureliano de Figueiredo Pinto até a Praça Garibaldi, por essa até a Av. Venâncio Aires, por essa até a Av. João Pessoa, por essa até a Av. Loureiro da Silva, por essa até a Avenida Borges de Medeiros, por essa até a Av. Praia de Belas, por essa até a Av. Aureliano de Figueiredo Pinto, ponto inicial.

O bairro Cidade Baixa é caracterizado por um encadeamento intrincado de usos e usuários. Ele é importante na formação da cidade de Porto Alegre, marcado pelos conflitos entre grupos de usuários (moradores e comerciantes) e por cíclicas polêmicas referentes aos horários de fechamento dos bares noturnos. Este contexto se aproxima da geração de tensões e conflitos abordada por Castells (2003), a qual seria motivada pela inter-relação entre indivíduos com diferentes identidades e atributos culturais.

\section{Contornos metodológicos}

A pesquisa aplicada consistiu em um estudo de caso, de natureza exploratóriodescritiva, realizado no bairro Cidade Baixa, em Porto Alegre, junto a seus respectivos moradores e comerciantes. Seu objetivo foi o de compreender o contexto do bairro Cidade Baixa e de seus usuários, bem como as percepções dos representantes do GT Cidade Baixa. Foram utilizadas as seguintes abordagens metodológicas: a) levantamento documental sobre o bairro Cidade Baixa notícias em jornais e internet; transcrição de audiências públicas); e b) observação simples incursões pelo bairro e conversas informais com usuários) e c) entrevistas semiestruturadas. 
As entrevistas foram realizadas com especialistas do bairro (membros do grupo de Trabalho Cidade Baixa e o presidente da Associação dos Moradores do bairro Cidade Baixa) a fim de compreender os valores e significados atribuídos ao bairro. Ainda, para identificar os principais fatores positivos e negativos locais. A entrevista foi adotada para realizar uma avaliação qualitativa em profundidade sobre a percepção dos usuários engajados com as questões do bairro.

Foram entrevistados os integrantes do Grupo de Trabalho Cidade Baixa, cinco pessoas, e o presidente da associação dos moradores do bairro no primeiro semestre de 2013. Inicialmente, a pesquisadora apresentou o tema e os objetivos da entrevista, explicando que elas precisariam ser gravadas. Em seguida, os entrevistados assinaram o Termo de autorização para entrevista e gravação de voz. As entrevistas foram gravadas e transcritas, sendo que todas visavam esclarecer os seguintes tópicos principais: a) relação do entrevistado com o bairro: histórico com o bairro e papel no Grupo de Trabalho ou associação; b) significados do bairro para o entrevistado: sentimento em relação ao bairro e o que vem em mente ao falar em Cidade Baixa; c) percepção acerca das características de alguns aspectos do bairro: comércio, cultura, segurança, moradia, trânsito e transporte, história e turismo; e d) avaliação geral do bairro: pontos positivos e negativos.

\section{Os valores e significados atribuídos à Cidade Baixa}

Os entrevistados possuíam diferentes históricos em relação ao bairro Cidade Baixa, bem como papéis e visões.

Eu sempre morei no Centro, morei 15 anos no Centro, mas sempre fui um frequentador, desde que vim para Porto Alegre. Aprendi a gostar do bairro, me instalei aqui, comprei meu apartamento, tenho meu negócio. Compramos o terreno aqui e montamos o nosso negócio. Essa é uma história de quase 10 anos. Então, desde que a gente começou aqui no bairro (Representante dos comerciantes no GT Cidade Baixa).

Foi a partir do GT, eu não tenho história com o bairro, mas eu me apaixonei pelo bairro, me apaixonei pelas pessoas, me apaixonei pelos movimentos. (...), já estive na Cidade Baixa tomando uma cerveja, já estive na Cidade Baixa em festa, já, mas eu não tinha nenhum tipo de convivência, eu não conhecia ninguém, o que aconteceu, a partir disso, nós começamos a construir o grupo e conseguimos construir a discussão e eu sempre falo que uma das coisas que mais deixa a gente feliz, numa grande reunião que nós fizemos com mais de 500 pessoas, isso está em ata da audiência pública da câmara de vereadores, com mais de 500 pessoas para a gente aprovar a questão do horário dos bares, nós tivemos aprovação de 99,9\% das pessoas, só três pessoas votaram contra, então isso é uma coisa que nos deixa muito 
feliz, a construção que foi feita, entre empresários, moradores, entre jovens, estudantes, e pessoas idosas, essa convivência. Conflitos, existem, qualquer esquina tem um conflito, mas a gente tenta trabalhar para que não se tenha o conflito (Representante da Prefeitura Municipal de Porto Alegre no GT Cidade Baixa).

Em 1935, era presidente da província o General da Província Flores da Cunha. E ele jogava ali na Rua Andrade e Neves, mais tarde teve a Sociedade Espanhola, que antes era o bar dos Caçadores, e o meu padrasto, foi maestro da rádio Farroupilha. Flores da Cunha descobriu ele em 1935, data do centenário da revolução Farroupilha. Aí Flores da Cunha disse, "Roberto, quero imediatamente uma Ópera tua, aí ele fez a Ópera Missões em 1936. (...) Já estou chegando na Cidade Baixa. Com essa ópera, ele conseguiu um bom dinheiro, com esse dinheiro e mais as economias das irmãs, eles compraram esta casa aqui na Rua da República. É a casa onde eu moro hoje. (...) por volta de 1961, por aí, eu era interno no Colégio Champagnat, bolsa de estudos eu tinha, ele conheceu a minha mãe. (...) E foi assim que a casa passou a ser também da minha mãe.(...) E ele deixou a casa em herança, para minha mãe. E aí minha mãe morreu e a casa ficou num inventário novo, e por enquanto, estou habitando com minha filha (Presidente da Associação dos Moradores do bairro Cidade Baixa).

Eu tenho dois momentos para falar sobre o bairro Cidade Baixa. Primeiro momento, como morador, eu residi no bairro por cerca de 10 anos, tempo que eu estava cursando a academia de polícia militar, de 91 a 2001, eu residia no bairro. E posterior, agora, de 2010 até 2013 , a gente está no comando da $2^{\text {a }}$ CIA do $9^{\circ}$, no qual a Cidade Baixa está incluída como um setor de responsabilidade territorial, e aí a gente exerce essa função (Representante da Brigada Militar no GT Cidade Baixa).

Eu acho que eles (bares e restaurantes) são uns dos nossos representados. O bairro da Cidade Baixa possui bastantes estabelecimentos da nossa área. Nós somos um sindicato que representa a hotelaria e a gastronomia de Porto Alegre e dentre isso, têm algumas áreas que foram eleitas pela população como áreas de entretenimento e lazer, porque se estabeleceram alguns estabelecimentos próximos, normalmente da nossa área. Penso que isso de uma forma ou de outra levassem cada vez mais empresários para aquela região (Representante do SINDIPOA $^{5}$ no GT Cidade Baixa).

Foi porque os moradores da Cidade Baixa, que me conheciam, meus eleitores, resolveram me procurar. E aí tivemos a acolhida, porque o problema era aonde fazer. E deu uma coincidência, por exemplo, na Sagrada Família, com o padre Egon (Representante da Câmara de Vereadores no GT Cidade Baixa).

No que se refere aos "significados do bairro para o entrevistado", o "sentimento em relação ao bairro" é positivo para todos os entrevistados. Os entrevistados revelaram ter sentimentos, tais como; paixão, amor, carinho e orgulho em relação ao bairro Cidade Baixa. Já "o que vem em mente ao falar em Cidade Baixa”, por sua vez, refletem características existentes no bairro, por exemplo: conter atividades culturais, o que o tornaria diferente; ter evoluído a partir do engajamento dos moradores e comerciantes; ter boas relações de vizinhança; ser bem localizado, com acesso e deslocamento facilitados; ser região voltada para o entretenimento e a boemia; dispor de diversidade de comércio.

\footnotetext{
${ }^{5}$ Sindicato de Hospedagem e Alimentação de POA e Região.
} 
A Cidade Baixa é paixão, é amor. É um bairro que eu gosto. Existe todo um parque cultural do bairro, ele é um bairro diferente. Tem bastante pessoas jovens, muitas pessoas idosas.Pela cultura e pela diversidade de bares que existe aqui no bairro a gente aprende a gostar cada vez mais (Representante dos comerciantes no GT Cidade Baixa).

Sentimento de carinho, muito grande, eu gosto muito das pessoas do bairro e a reciprocidade delas junto comigo é fabulosa, eles me veem como um amigo do bairro, de tentar facilitar todas as questões para eles, de tentar ajudar, eu tenho um sentimento de muito carinho. Vem tanta coisa na minha mente, eu acho que a Cidade Baixa evoluiu muito, mas não pela prefeitura, a prefeitura foi apenas uma parceira daquele processo ali, eu acho que eles evoluíram como pessoas, eles evoluíram como ser humano, como cidadão de Porto Alegre (Representante da Prefeitura Municipal de Porto Alegre no GT Cidade Baixa).

Eu adoro isso aqui. É a minha casa, eu gosto. Olha só essa rua aqui. Se tu vier aqui nessa rua na segunda-feira, de noite, a maioria dos bares não abre, tu vais verificar como era a Cidade Baixa antes. As pessoas aqui, eu conheço todos os meus vizinhos, nós nos damos. Seis da manhã eu sento ali na frente para tomar meu chimarrão, de repente chega um vizinho que está acordando, chega outro, e a gente conversa, troca ideia. Isso aqui tem um jeitinho de interior (Presidente da Associação dos Moradores do bairro Cidade Baixa).

Eu vejo a cidade baixa como um bairro bem interessante para quem mora no bairro. É um bairro que tem muitos atrativos, atividades culturais, são as casas, (...) que têm um compromisso social melhor de trabalhar e prestar um serviço à comunidade bom. (...) Eu vejo um bairro que avançou, um bairro que melhorou (Representante da Brigada Militar no GT Cidade Baixa).

Eu acho ela uma pérola no meio de uma cidade cosmopolita. É isso que eu enxergo dela. É um bairro que, se não cuidarmos, ele se perde. Facilidade próxima à região do movimento, dessa coisa de ter entretenimento, é um bairro boêmio. A Cidade Baixa tem uma peculiaridade de clientela, turma mais jovem, com poder aquisitivo de classe média, tu tens facilidade, tu tens uma boa relação (Representante do SINDIPOA no GT Cidade Baixa).

Bom, a Cidade Baixa, o que eu vejo, as pessoas que moram lá, elas têm um orgulho muito grande de dizer que são moradores da cidade baixa. Um lugar mais próximo do centro da cidade, é um lugar que tu não precisa ter carro para se deslocar, tu poder ir para o Centro à pé, se tu não quiser pegar o ônibus. É um lugar que tu tem tudo ali no entorno, tem essa vida boêmia que a gente estava falando, mas tem um bom comércio, tem banco, tem cartório, tem feira livre, tem supermercado. É um bairro que te permite tu ficar ali o tempo todo (Representante da Câmara de Vereadores no GT Cidade Baixa).

No que diz respeito à percepção dos entrevistados sobre o tema "comércio" no bairro Cidade Baixa, foi recorrente nas falas que o bairro dispõe de ampla diversidade de comércio voltado para atender o público local. Também foi mencionada a forte presença de estabelecimentos voltados para área de gastronomia, entretenimento e lazer: bares, restaurantes, pubs e casas noturnas. Cabe salientar que um dos entrevistados, por ser representante da Brigada Militar, enfatizou a questão da segurança, entendendo que o comércio usufrui de segurança para funcionar. 
Bem diversificado; bastante área de gastronomia e entretenimento (Representante dos comerciantes no GT Cidade Baixa).

Quem mora ali não precisa sair do bairro; tem todo o tipo de comércio; pets, bancos, supermercados, bares e restaurantes (Representante da Prefeitura Municipal de Porto Alegre no GT Cidade Baixa).

É muito bom; tem público próprio; encontra-se tudo que se procura; é uma cidade dentro de Porto Alegre; tem shopping, supermercados (Presidente da Associação dos Moradores do bairro Cidade Baixa).

Tranquilo, poucos casos de roubo e furto (Representante da Brigada Militar no GT Cidade Baixa).

Muito pequenos negócios que atendem ao público interno; lojinhas, brechós, loterias, padarias; e bares e restaurantes (Representante do SINDIPOA no GT Cidade Baixa).

É forte, é um pequeno negócio, mas rico; pequenos comerciantes; infinidade de lojinhas (Representante da Câmara de Vereadores no GT Cidade Baixa).

No que diz respeito à percepção dos entrevistados sobre o tema "cultura" no bairro Cidade Baixa, todos esboçaram reconhecer que a cultura é uma das vocações do bairro e que é uma das referências dentro de Porto Alegre por esse motivo. Foram percebidos pelos entrevistados a diversidade de atividades e manifestações culturais, com a presença de muitos músicos, shows, teatro, carnaval de rua. Ainda foi recorrente a menção ao Museu Joaquim Felizardo, à Travessa dos Venezianos e o bar Opinião como referência de locais que expressam cultura dentro do bairro.

Todo mundo conhece; ótima (Representante dos comerciantes no GT Cidade Baixa). Atividades culturais; manifestações culturais diversas (Representante da Prefeitura Municipal de Porto Alegre no GT Cidade Baixa).

A Cidade Baixa é sinônimo de cultura; teatro; moram muitos músicos; Shows (Presidente da Associação dos Moradores do bairro Cidade Baixa).

Bem latente no bairro, eventos, museu, teatro, cultura (Representante da Brigada Militar no GT Cidade Baixa).

Está tentando se resgatar, carnaval de rua, manifestações artísticas muito locais, diversificação cultural muito grande, conviver com culturas diferentes (Representante do SINDIPOA no GT Cidade Baixa).

Museu Joaquim Felizardo; Travessa dos Venezianos; Bar Opinião; vários lugares com música ao vivo; produções culturais, surgem artistas novos; tem todo o tipo de música (Representante da Câmara de Vereadores no GT Cidade Baixa). 
A percepção dos entrevistados sobre o tema "segurança" no bairro Cidade Baixa foi apreendida em suas falas como questão que ainda não atingiu patamares satisfatórios, apesar de ter melhorado. Nessa direção, a maioria dos entrevistados mencionou a necessidade de aumento de dispositivos que ampliam a segurança no bairro, por exemplo: aumento do policiamento ostensivo e a ampliação da iluminação pública. Ainda, o representante da Brigada Militar informa que as ocorrências no bairro concentram-se em furto simples e de veículos.

Precisa aumentar o policiamento ostensivo; pouca iluminação em certas ruas (Representante dos comerciantes no GT Cidade Baixa).

Está melhorando (Representante da Prefeitura Municipal de Porto Alegre no GT Cidade Baixa).

Péssima, não tem; as vezes contamos com a Brigada Militar (Presidente da Associação dos Moradores do bairro Cidade Baixa).

Furto de veículos, furto simples, falta de iluminação, áreas com poucas pessoas (Representante da Brigada Militar no GT Cidade Baixa).

Tem que ter, é fraca; precisa de mais policiamento ostensivo; ter um posto da BM direto, dia e noite (Representante do SINDIPOA no GT Cidade Baixa).

Evoluiu bastante; é cíclico, tem épocas que melhora e outras que piora (Representante da Câmara de Vereadores no GT Cidade Baixa).

Sobre a percepção dos entrevistados ao que se refere ao tema "moradia" no bairro Cidade Baixa, muitos se manifestaram positivamente. O bairro é considerado bom para os moradores, pois dispõem de diversidade de comércio e serviços. Foi mencionado ainda que, pelo fato da comunidade ser engajada nas questões do bairro, ele tende a alcançar melhoras maiores. Foi lembrado ainda que muitas das moradias consistem em prédios e casas antigos, bem como de apartamentos pequenos para estudantes e famílias pequenas. Apesar de a Cidade Baixa apresentar alguns problemas com o barulho provocado pela vida noturna, é considerado um bairro valorizado no mercado imobiliário.

É bom demais morar no bairro, porque tem tudo (Representante dos comerciantes no GT Cidade Baixa).

É muito bom de se morar lá pela questão do convívio das pessoas (Representante da Prefeitura Municipal de Porto Alegre no GT Cidade Baixa).

Era um paraíso, era muito bom; hoje não se consegue ter sossego para dormir (Presidente da Associação dos Moradores do bairro Cidade Baixa). 
Comunidade atuante, lideranças que pedem segurança e tranquilidade (Representante da Brigada Militar no GT Cidade Baixa).

Moradias mais antigas; Prédios muito antigos; apartamentos pequenos para estudantes e famílias menores; bairro valorizado; poucas tem garagem (Representante do SINDIPOA no GT Cidade Baixa).

Grande parte são moradias antigas; têm várias residências com história própria (Representante da Câmara de Vereadores no GT Cidade Baixa).

No que tange à percepção dos entrevistados sobre o tema "trânsito" no bairro Cidade Baixa, as entrevistas revelaram que um dos fatores que geram problemas no seu fluxo foi a colocação de uma ciclovia. A ciclovia teria reduzido a dimensão da via e também os espaços reservados para estacionamento, o que contribuiria significativamente para o engarrafamento em horários de pico. Outro aspecto elencado nas entrevistas é a insuficiência de espaços para estacionamento, o que resultaria em prejuízo para o bom fluxo no trânsito, bem como para o comércio, que reteria maior número de clientes.

Problema com a ciclovia (engarrafamento). Falta de estacionamento (Representante dos comerciantes no GT Cidade Baixa).

Os comerciantes não querem a ciclovia, eles querem o estacionamento que tiraram deles (Representante da Prefeitura Municipal de Porto Alegre no GT Cidade Baixa).

Está ruim. Não temos mais garagens (Presidente da Associação dos Moradores do bairro Cidade Baixa).

A gente tem umas vias ali com problemas, A José do Patrocínio é uma avenida que não é larga, ela é estreita, ela tinha 3 pistas, com o advento da ciclovia, foi reduzida para duas. Foi criada uma ciclovia e mais um estacionamento. No horário compreendido entre as $19 \mathrm{~h}$ que o pessoal sair e quer ir para casa, o trânsito tranca e não flui, não tem fluidez (Representante da Brigada Militar no GT Cidade Baixa).

Hoje mesmo, eu não entendi porque que botaram aquela ciclovia ali, eu não entendi aquilo, não consegui perceber ainda, se a ciclovia, ela é mais importante que uma rua de fluxo; muitas moradias não têm garagem (Representante do SINDIPOA no GT Cidade Baixa).

O grande problema é que fizeram a ciclovia e um estacionamento do lado, estreitando a pista. Engarrafamento (Representante da Câmara de Vereadores no GT Cidade Baixa).

No que se refere à percepção dos entrevistados sobre o tema "transporte" no bairro Cidade Baixa, foi recorrente a afirmação de que o bairro é privilegiado pela grande oferta de transporte público. Ainda, foi mencionado que alguns passageiros (frequentadores noturnos) reclamam da pouca oferta de ônibus depois da meia-noite. A 
oferta de opções de transporte nesses horários incrementaria a diversidade de usos e usuários no bairro.

Temos muitas linhas de ônibus (Representante dos comerciantes no GT Cidade Baixa).

Acho que nós estamos muito bem atendidos com os ônibus da Carris, com um serviço de qualidade (Representante da Prefeitura Municipal de Porto Alegre no GT Cidade Baixa).

A maioria deles passa por aqui para fazer o fim de linha no centro ali. Tu pegas ônibus fácil (Presidente da Associação dos Moradores do bairro Cidade Baixa).

Muito transporte coletivo (Representante da Brigada Militar no GT Cidade Baixa).

Então eu acho que eles são bem abastecidos (Representante do SINDIPOA no GT Cidade Baixa).

O transporte do bairro é normal, é relativamente bom. O passageiro, por sua vez, reclama que gostariam que tivessem mais ônibus, principalmente nessa época que está a lei seca aí, que ele podia tomar todas e ir embora de ônibus (Representante da Câmara de Vereadores no GT Cidade Baixa).

Com relação à percepção dos entrevistados sobre o tema "história" do bairro Cidade Baixa, muitos fizeram referência à Cidade Baixa com um bairro de vocação boêmia, alicerçando suas argumentações em torno do da vida noturna existente antigamente. Vinculam a história do bairro enquanto boêmio ao cantor e compositor Lupicínio Rodrigues; aos carnavais de rua; às festas da população negra em décadas passadas. As construções antigas também são lembradas como parte do acervo histórico do bairro, por exemplo, a Travessa dos Venezianos com seus casarios e calçadas antigos.

A história do bairro Cidade Baixa, desde o Lupicínio Rodrigues, o que vem na mente é a parte cultural, com música, diversão, entendeu, é cultura, então isso aí é cada vez mais (Representante dos comerciantes no GT Cidade Baixa).

Eu sei que me falaram que em alguns cantos ali era um lago, e hoje o bairro está todo nesta questão cultural que sempre foi assim, não fugiu muito das origens lá atrás, na construção do bairro, mas eu não posso te falar muito da história assim (Representante da Prefeitura Municipal de Porto Alegre no GT Cidade Baixa).

Aqui onde está essa linha dos edifícios, e onde fica a minha casa, antigamente eram os muros da cidade. Aqui eram os muros da cidade. Do lado de fora dos muros, ficavam o Arraial da Baronesa e os quilombolas (Presidente da Associação dos Moradores do bairro Cidade Baixa). 
É uma história rica, temos dentro do bairro um quilombo, dentro do bairro cidade baixa, tem a história do carnaval de porto alegre, ligado ao bairro cidade baixa, é um bairro extremamente rico de histórias ligadas justamente a esta atividade cultural que se fala (Representante da Brigada Militar no GT Cidade Baixa).

Não conheço muito, não sei dizer assim, eu só sei que ele se formou, eu sei de hoje, das dificuldades que o bairro tem hoje, a história dela eu não conheço muita coisa (Representante do SINDIPOA no GT Cidade Baixa).

Eu ouço muito falar dessa questão da Travessa dos Venezianos, da questão da rua do perdão, que eles falam que é parte da República, que onde teria surgido o carnaval de Porto Alegre, depois, o pessoal faz uma mistura, que não é na Cidade Baixa, e alguns entendem que ali seria Cidade Baixa também, que é a questão da famosa Ilhota, que é a vila Lupicínio Rodrigues (Representante da Câmara de Vereadores no GT Cidade Baixa).

Em referência à percepção dos entrevistados sobre o tema "turismo" no bairro Cidade Baixa, mais uma vez são abordados aspectos referentes à história do bairro, suas construções antigas, os quais poderiam atender a interesses turísticos. A grande concentração de atividades de entretenimento e lazer noturno e a localização privilegiada do bairro colaboraria para receber turistas de diversos lugares do estado, país e exterior. Mesmo o bairro apresentando aspectos que favorecem o turismo, alguns entrevistados consideram importante investir mais em segurança e infraestrutura para qualificá-lo.

Todo esse casario antigo, então, essa história de boemia que o bairro da Cidade Baixa tem, museus, teatros, então tem bastante pontos aqui, Praça Garibaldi, tem bastante coisa bonita aqui para se mostrar aqui no bairro (Representante dos comerciantes no GT Cidade Baixa).

O bairro tem muito a oferecer para os turistas, muito, tudo, tem cinema, tem teatro, tem tudo. A cidade Baixa tem a noite, tem os restaurantes, os bares, os pubs, as pessoas (Representante da Prefeitura Municipal de Porto Alegre no GT Cidade Baixa).

A Cidade Baixa, talvez por ser tão próxima do centro, foi escolhida para isso (Presidente da Associação dos Moradores do bairro Cidade Baixa).

A gente tem, na João Alfredo, as casas preservadas, que são as construções antigas, do século passado, que são construções preservadas, conservadas (Representante da Brigada Militar no GT Cidade Baixa).

É muito recomendado como um bairro a ser visitado na cidade, mas ele precisaria um pouco mais de tranquilidade, que ele seja CUIDADO, que tenha guarda na rua, que tenha limpeza urbana mais adequada (Representante do SINDIPOA no GT Cidade Baixa).

Ele é um bairro de vocação turística muito grande, está inserido (Representante da Câmara de Vereadores no GT Cidade Baixa). 
No que concerne à "avaliação geral do bairro", para os entrevistados, os "pontos positivos" estão associados a ser um lugar bom para viver. Tal perspectiva está apoiada na diversidade de usos que o bairro proporciona, por exemplo: escolas, lojas, supermercados, cinema, teatro; bancos; cultura; lazer; proximidade do Parque Farroupilha (Redenção) e Shopping Praia de Belas; localização privilegiada, acessibilidade, áreas verdes; bem como diferentes tipos de estabelecimentos voltados para o entretenimento noturno. Da mesma maneira, os pontos positivos são focados para a diversidade de usuários que o bairro congrega; a busca de boa convivência entre diferentes usuários; o engajamento de moradores e comerciantes em prol das necessidades do bairro. Ainda, tem-se como aspecto favorável a história, as construções antigas e atividade culturais que o bairro comporta.

Vários, é um lugar muito bom de se morar, de se viver, tem teatro, tem cultura, tem a Redenção aqui do lado, tem bons restaurantes, temo shopping aqui que é o Praia de Belas que fica do lado do bairro, tem todos os bancos aqui na Cidade Baixa, tem cultura, tem lazer, tem tudo aqui na Cidade Baixa, o que tem que melhorar é a segurança para que a gente possa vender melhor o nosso bairro, para que as pessoas venham ao nosso bairro com segurança (Representante dos comerciantes no GT Cidade Baixa).

Convivência, convivência entre todo mundo, entre todos, todos, acho que a convivência é um dos aspectos mais positivos no bairro. Convivência e a alegria do bairro. Tu entra no bairro e tu vê ele plenamente alegre, então eu acho ele maravilhoso, acho que não tem outra palavras para descrever oque eu acho da Cidade Baixa, eu acho que é o exemplo, acho que o bairro Cidade Baixa é exemplo a ser seguido para muitos bairros e para muitas pessoas também. Eu acho que ali nós demos um exemplo de democracia, de construção coletiva, e a gente vai avançar mais ainda, acredito que a gente vai avançar muito mais (Representante da Prefeitura Municipal de Porto Alegre no GT Cidade Baixa).

Para mim, Porto Alegre é o bairro Cidade Baixa. Para mim Porto Alegre é aqui. Para mim, a importância é total. Para mim, Porto Alegre é a grande Cidade Baixa. Tudo gira em torno de nós aqui, inclusive o centro e o governo do estado e tudo mais (Presidente da Associação dos Moradores do bairro Cidade Baixa).

Tem uma comunidade atuante, tem uma liderança. Existe uma harmonia entre os moradores e os comerciantes, proprietários dos estabelecimentos do bairro. Eles conseguem conversar entre eles, entenderem as dificuldades do bairro, e buscara juntos, uma ajuda, um atendimento às suas demandas. Falando parece uma coisa simples, mas na prática é uma coisa complicada, tu conseguir conciliar interesses diversos, buscando entendimento comum, e eles conseguem fazer isso. Isso aí é um ponto muito positivo do bairro que a gente observa. Outro aspecto positivo do bairro, a gente vê que é um bairro, que ele é, na Cidade Baixa, ele é plano, ele é planificado, isto facilita, por exemplo, a criação das ciclovias, facilita porque é um bairro plano, e facilita para que as pessoas possam caminhar, andar de bicicleta, circular pelo bairro tranquilamente. É um bairro que tem um atendimento de escolas de uma forma interessante, têm escolas, bastante escolas. Têm atendimento de supermercado, tem um grande mercado no bairro. Que mais que o bairro tem... A história do bairro é positiva, porque as pessoas de identificam com a história. E entretenimento, também, para o público jovem, é muito interessante no bairro 
Cidade Baixa, tem ali 3 vias que têm casas distintas para tudo quanto é tipo de jovens, por exemplo, se gosta de um tipo de música, um tipo de outra, ele consegue atender isso aí. Isso é positivo no bairro (Representante da Brigada Militar no GT Cidade Baixa).

A proximidade é um, o encantamento que ele ainda tem por ser um bairro praticamente, ele não tem muitas construções novas, ele ainda tem muitas casa antigas, ainda tem muito dessa coisa de uma cidadezinha do interior,ele tem muito essa característica, acho que assim, arquitetonicamente acho bem bonito, bem interessante, acho que tem bastante verde lá, acho que a gente pode considerar isso uma coisa positiva, eu acho que esse conflito entre, na verdade não é conflito, de ter negócios $24 \mathrm{~h}$ abertos, tu tens tudo quanto é publico ali, acho também uma característica bem interessante, tu tens criança, tu tens pessoas mais velhas, tu tens a mulher que faz as compras no Zaffari, tu tens os bares noturnos, tu tens gente que vem da balada, tu tens que vem de outras regiões, eu acho que esse mix assim muito interessante, eu acho interessante (Representante do SINDIPOA no GT Cidade Baixa).

O ponto mais positivo é a população. É que, quando uma população mora e gosta, isso aí já é o primeiro indicativo para mim, o segundo, a população que são uma outra população, que são os usuários, os frequentadores, que vão para aquele lugar e também se sentem bem, é um lugar que eles vão e se sentem dono, então, isso aqui, para mim, é o ponto mais positivo. Outros pontos, á a proximidade do Centro da Cidade, é um lugar de fácil acesso, tem escoamento para qualquer lugar da cidade (Representante da Câmara de Vereadores no GT Cidade Baixa).

Já os "pontos negativos", por sua vez, refletem-se, a partir das entrevistas, nas questões relativas à infraestrutura, contra-uso, acessibilidade e segurança. No tocante à infraestrutura, foram recorrentes os comentários sobre problemas de iluminação, pavimentação (ruas e vias) e limpeza urbana. Quanto aos contra-usos, a maioria dos entrevistados identificou a ocupação de moradores de rua ou guardadores de veículos como um dos pontos mais negativos. No que concerne à acessibilidade, foi identificado o problema de circulação de veículos (engarrafamento) e falta de estacionamento suficiente para acolher a demanda atual do bairro. Ainda, foi identificado por um entrevistado um aspecto da área de conforto ambiental, qual seja, o nível de ruído ambiental elevado por causa da movimentação noturna do bairro.

Segurança e os moradores de rua são mais fortes, pavimentação e iluminação eficaz, a iluminação é precária em certos pontos. O que gera insegurança para os moradores. Os moradores de rua estragam a imagem da Cidade Baixa, não que a gente não goste deles entendeu, por exemplo, eu contrato alguns para fazerem pequenas obras quando preciso, preciso carregar areia, brita e tal. Tem gente lá que são trabalhadoras, eu já sugeri para FASC criar um trabalho para esse povo. Tem uma parcela que são trabalhadores, mas aí eles vão gastar o dinheiro com crack (Representante dos comerciantes no GT Cidade Baixa).

Acho que eu vou na questão da limpeza, a questão é que falta um pouquinho de educação das pessoas. Isso eu acho um ponto negativo, mas eu não generalizo o bairro, generalizo as pessoas, algumas pessoas. Eu acho que falta um pouquinho de educação de algumas pessoas que não querem participar de nada, eu acho que a 
palavra negativa é a falta de educação de um setor, de algumas pessoas, no mais não vejo aspectos negativos muito grandes no bairro (Representante da Prefeitura Municipal de Porto Alegre no GT Cidade Baixa).

Sempre os mesmos, barulho, abuso de bares, é sempre o mesmo. Na rua da República, João Alfredo, José do Patrocínio, na Joaquim Nabuco, etc (Presidente da Associação dos Moradores do bairro Cidade Baixa).

É o problema de circulação de veículos, as vias não comportam a demanda, principalmente naqueles horários de pico. Alguns pontos de iluminação é preciso ser revistos, muitas vezes é problema de arborização, as árvores estão com a copa muito alta, e isso dificulta a iluminação. E também, um outro aspecto negativo do bairro é justamente essas casas de acolhimento que não têm condições de atender a demanda suficiente para as pessoas que procuram. E essas pessoas ficam na rua, além de ser uma condição desumana para o ser humano, nós estamos ainda entrando no inverno, e essas pessoas vão sofrer as intempéries ali, de não ter onde ficar, isso é um ponto extremamente negativo que eu acho, no bairro Cidade Baixa. (...) Outra questão são os guardadores de veículos, vulgo flanelinhas, que vieram para a cidade baixa porque aumentou a circulação de pessoas, isso eles identificaram ali como um ganho de dinheiro, de fazer aquela prestação de serviço, em tese, para guardar os veículos. Então, isso gera um problema entre moradores, frequentadores, jovens, e esses guardadores de veículo (Representante da Brigada Militar no GT Cidade Baixa).

E os pontos negativos que eu acho é isso. Ele não tem segurança, ele não tem limpeza, não tem estacionamento, ele está um pouco descuidado (Representante do SINDIPOA no GT Cidade Baixa).

O que eu vejo é melhorar a iluminação pública do bairro, aquilo que foi feito na João Alfredo tem que ser feito em toda ela. E Porto Alegre assumir, como aquele ponto é um bairro boêmio da cidade, o bairro da diversão, da gastronomia, do lazer, da recreação (Representante da Câmara de Vereadores no GT Cidade Baixa).

Os resultados obtidos corroboram que o bairro Cidade Baixa é um território permeado por uma intrincada diversificação de usos. Ainda, que a Cidade Baixa é portadora de relevância histórica e cultural tanto pelos seus marcos históricos presentes no bairro quanto por sua cultura de boemia presentes no imaginário de seus usuários. Por fim, que a sobreposição de usos e usuários geram cíclicos processos de conflitos e negociações.

\section{À guisa de conclusão}

Verifica-se que o bairro é palco de conflitos devido à coexistência de ampla diversidade de usos, apresentando uma certa polarização entre os usuários moradores e comerciantes/frequentadores. Nesse sentido, os constantes processos de negociação entre os usuários viabilizou uma melhora na sua convivência. Cabe ressaltar que o bairro passou a ser referência para solução de conflitos, face ao engajamento dos usuários. 
O bairro Cidade Baixa possui diversas vocações (residencial, boêmia, histórica). A sobreposição de usos e usuários é permeada por cíclicos processos de conflito e negociação em razão da vida noturna do bairro. Dentro desse contexto, foi possível identificar três grupos de usuários principais: moradores, comerciantes e freqüentadores e reconhecer que dois grupos de usuários são engajados com as questões do bairro: moradores e comerciantes.

A fundamentação teórica sobre território e suas derivações foram importantes na caracterização do bairro enquanto espaço funcional e simbólico. A constituição material do território enquanto base de recursos se reflete na Cidade Baixa através de suas características e atributos, por exemplo, seus equipamentos urbanos. A dimensão funcional (Haerbaert, 2004) no bairro Cidade Baixa comporta elementos concretos que buscam satisfazer as necessidades de seus usuários, quais sejam: moradia, comércio e serviços, transporte e infraestrutura. Já a composição imaterial do território enquanto símbolo se traduz no bairro em aspectos abstratos. A esfera simbólica do bairro Cidade Baixa dispõe de elementos que produzem significados para seus usuários, por exemplo, história, diversidade cultural, patrimônio histórico e vida boêmia.

A partir das entrevistas, foi possível identificar as principais características do bairro para os respondentes. A avaliação positiva do bairro se deu face à diversidade de usos e usuários; áreas verdes; boa localização; diversidade de áreas de entretenimento noturno; busca de boa convivência; engajamento de moradores e comerciantes; história e patrimônio; e atividades culturais. Por sua vez, a avaliação negativa emergiu devido à deficiências na infraestrutura (iluminação, pavimentação e limpeza urbana); ao contrausos (realizados por moradores de rua, flanelinhas, delinquentes, vândalos, etc.); congestionamento do trânsito; falta de estacionamentos; oferta insuficiente de segurança; e ruído ambiental (movimentação noturna).

A intensa diversidade do Bairro Cidade Baixa revela o que, nas palavras de Jane Jacobs (2011), seria a vitalidade do bairro. Entretanto essas sobreposições de usos e usuários geram cíclicos processos de conflito e negociação. Neste sentido, esse tipo de contexto se aproxima da geração de tensões e conflitos abordada por Castells (2003), a qual seria motivada pela inter-relação entre indivíduos com diferentes identidades e atributos culturais. Ao mesmo tempo, quando o bairro é permeado por usuários em situação de engajamento com as questões locais, é possível verificar que as relações de conflito entre os diversos grupos urbanos que o utilizam são enfraquecidas. 
Conforme mencionado anteriormente, o bairro Cidade Baixa tem diversidade cultural, boemia, e relevância histórica para a cidade de Porto Alegre. A identificação com esse conjunto de características se revela importante para os grupos de usuários estudados, pois ao longo do tempo foram se apropriando desses significados e vinculando à sua identidade. Nessa direção, Castells (2003) explica que a identidade é um dos elementos de maior relevância na constituição do espaço, que é socialmente construída, e que seus significados e símbolos são produzidos pelos próprios atores que as constroem. Ainda, segundo Gravano (2003), o conceito de lo barrial envolve tanto a dimensão material quanto a simbólica. Nessa última, os valores e significados surgem no discurso da população local. Dessa forma se reforça a importância de analisar a relação entre as características mais concretas e os componentes simbólicos na percepção dos usuários.

Em suma, é possível observar que o bairro Cidade Baixa tem várias vocações: território de lazer, corredor de vida noturna com sua cultura de boemia, bem como seu patrimônio histórico. O que se reflete na sobreposição de usos e seus constantes processos de conflito e negociação. O que pode ser ilustrado pelas relações de confronto de quem utiliza e de quem mora no bairro, que são resultantes dos barulhos e dos movimentos nas ruas à noite. Nesse contexto, a percepção dos usuários se revela importante, uma vez que contribui para a compreensão dos aspectos positivos e negativos do bairro, bem como dos valores e significados associados a ele. Abordagens dessa natureza podem implicar em trabalhos futuros que auxiliem na qualificação dos bairros, equacionando os interesses dos distintos grupos de usuários que ali coexistem. 


\section{Referências}

BARCELlOS, Tanya M. Região Metropolitana de Porto Alegre: expansão urbana e dinâmica imobiliária nos anos 90. Indicadores Econômicos. Porto Alegre: FEE, v. 32, n. 1, maio de 2004, p.65-90.

BEZERRA, Josué A. A reafirmação do bairro: um estudo geo-histórico do bairro do Alecrim na cidade de Natal. 2005. 187 f. Dissertação (Mestrado em Geografia) - Centro de Ciências Humanas, Letras e Artes, Universidade Federal do Rio Grande do Norte, 2005.

BONNEMAISON, Joel. Viagem em torno do território. In: CORREA, R.L.;

BOSI, Ecléa. Memória e Sociedade: lembranças de velhos. São Paulo: Cia das Letras, 2009.

CASTELLS, Manuel. O poder da identidade. A era da informação: economia, sociedade e cultura. 3 ed. Lisboa: Fundação Calouste Gulbenkian. Vol. II. 2003.

CERTEAU, Michel de. A invenção do cotidiano: artes de fazer. Petrópolis: Vozes, 1998.

CLARO, Ceciliano S. O bairro Cidade Baixa e seu desenvolvimento histórico. Prefeitura Municipal de Porto Alegre. EPHC. Núcleo de pesquisa e documentação. Porto Alegre, 1997.

COGO Paulo S. A "Olaria dos Narcisos": um estudo sociológico da oferta e do consumo de lazer no centro comercial Nova Olaria de Porto Alegre - V. 2: Anexos (Mestrado em Sociologia) Programa de Pós-Graduação em Sociologia da Universidade Federal do Rio Grande do Sul, Porto Alegre, 1999 b.

COGO Paulo S. A "Olaria dos Narcisos": um estudo sociológico da oferta e do consumo de lazer no centro comercial Nova Olaria de Porto Alegre (Mestrado em Sociologia) Programa de Pós-Graduação em Sociologia da Universidade Federal do Rio Grande do Sul, Porto Alegre, 1999 .

CORRÊA, Roberto Lobato. O espaço Urbano. $4^{\mathrm{a}}$ ed. São Paulo: Ática, 1999.

ECKERT, Cornélia; ROCHA, Aana. L. C. O tempo e a cidade. Porto Alegre, Ed. UFRGS, 2005.

ECKERT, Cornélia. A Cultura do Medo e as Tensões do Viver na Cidade: narrativa e trajetória de velhos moradores de Porto Alegre. In: MYNAIO, Maria Cecília de S.,

FIGUEIREDO, Marina D. "O Muro Invisivel": Cultura organizacional $e$ representações sociais no centro comercial Nova Olaria. Dissertação de Mestrado Programa de Pós-Graduação em Administração, Universidade Federal do Rio Grande do Sul, Porto Alegre, 2008.

FONSECA, Luciana M. Dois rumos na noite de Porto Alegre: dinâmica socioespacial e lazer noturno nos bairros Cidade baixa e Moinhos de Vento. 2006. Dissertação de Mestrado. UFRGS, Porto Alegre, 2006.

FRANCO, Sérgio C. Porto Alegre: Guia Histórico. 3 ed. Porto Alegre: EdUFRGS, 1998.

FRYDBERG, Mariana B. Lupi, Se Acaso Você Chegasse: um estudo antropológico das narrativas de Lupicínio Rodrigues. Dissertação de Mestrado. UFRGS, 2007.

GERMANO, Íris G. Rio Grande do Sul, Brasil e Etiópia: os negros e o carnaval de Porto Alegre nas décadas de 30 e 40. Dissertação de Mestrado. UFRGS, 1999.

GONÇALVES, Antonio C. Os bairros urbanos como lugares de práticas sociais. Revista da Faculdade de Letras - Geografia I Série. Vol. IV - Porto, 1988. p. 15 a 31.

GRAVANO, Ariel. Antropología de lo barrial: estudios sobre producción simbólica de la vida urbana. Buenos Aires: Espacio, 2003. 
GRAVANO, Ariel. El Barrio en la Teoría Social. Buenos Aires: Editorial Espacio, 2005.

HAESBAERT, Rogério. Des-territorialização e Identidade: a rede "gaúcha" no Nordeste. Niterói: EDUFF, 1997.

HAESBAERT, Rogério. Da Desterritorialização a Mutiterritorialidade. Anais do $X$ Encontro de Geógrafos da América Latina - 20 a 26 de março de 2005 - Universidade de São Paulo.

HAESBAERT, Rogério. Des-territorialização e identidade: a rede "gaúcha" no nordeste. Niterói: EdUFF, 1997.

HAESBAERT, Rogério. O mito da desterritorialização: do "fim dos territórios" à multiterritorialidade. 3.ed. Rio de Janeiro: Bertrand Brasil. 400 p. 2007.

HAESBAERT, Rogério. Dos múltiplos territórios à Multiterritorialidade. In: Seminário Internacional sobre Múltiplas Territorialidades, 2004. Documento de trabalhoelaborado a partir de uma versão revisada de uma de um documento apresentado no $1^{\circ}$ Seminário Nacional sobre múltiplasterritorialidades. Porto Alegre: UFRGS, 23 set. 2004.

HAESBAERT, Rogério. Territórios Alternativos. São Paulo: Contexto, 2006.

HALL, Stuart. Identidade Cultural na Pós-Modernidade. Rio de Janeiro: DP\&A, 2006.

JACOBS, Jane. Morte e vida das grandes cidades. São Paulo: Martin Fontes, 2011.

JARDIM, Denise F. De bar em bar: identidade masculina e auto-segregação entre homens de classes populares. Dissertação de mestrado. Universidade Federal do Rio Grande do Sul. Instituto de Filosofia e Ciências Humanas. Programa de Pós-Graduação em Antropologia Social, 1991.

LYNCH, Kevin. A Boa Forma da Cidade. Lisboa: Edições 70, 2007.

LYNCH, Kevin. A Imagem da cidade. São Paulo: Martins Fontes, 2010.

MARQUES, Olavo R. Entre a Avenida Luiz Guaranha e o Quilombo do Areal: Estudo etnográfico sobre memória, sociabilidades e territorialidade negra em Porto Alegre/RS. Dissertação de Mestrado. UFGRS, 2006.

MAYOL, Pierre. Morar. In: CERTEAU, M.; GIARD, L.; Mayol: A invenção do cotidiano: 2. Morar, cozinhar. Petrópolis: Vozes, 1998.

MENEGOTTO, Renato. Cidade Baixa: pela manutenção dos cenários de um barro tradicional de PortoAlegre. Dissertação de mestrado, PPG de História, PUCRS. Porto Alegre, 2001.

MILLAN, Santiago. O mestre Borel: ancestralidade negra em Porto Alegre. Iluminuras, Porto Alegre, v. 14, n. 33: 327-330, jul./dez. 2013.

PESAVENTO, Sandra J.Lugares malditos: a cidade do "outro" no Sul brasileiro (Porto Alegre, passagem do século XIX ao século XX) Rev. bras. Hist. vol.19 n.37 São Paulo Sept. 1999.

RAFFESTIN, Claude. Por uma geografia do poder. São Paulo: Ática, 1993.

RECKZIEGEL, Daniela. Lazer Noturno: aspectos configuracionais e formais e sua relação com a satisfação e preferência dos usuários. Dissertação de Mestrado. UFRGS, Porto Alegre, 2009.

RONCAYOLO, Marcel. La ville et ses territoires. Paris: Gallimard, 1990.

SANTOS, Irene. Colonos e Quilombolas. Memória fotográfica das colônias africanas de Porto Alegre.. Secretaria Municipal da Cultura. Prefeitura Municipal de Porto Alegre: Porto Alegre, 2010.

SAPIEZINSKAS, Aline. Travessa dos Venezianos: um estudo antropológico sobre os significados da casa tombada para os seus moradores. Dissertação (Mestrado em Antropologia Social)-PPGAS, Universidade Federal do Rio Grande do Sul, Porto Alegre, 2004. 
SILVA, Michelle N. Identidade, pertencimento e sociabilidade no espaço urbano: observações sobre a percepção dos usuários do bairro Cidade Baixa em Porto Alegre. Iluminuras, Porto Alegre, v. 14, n. 34: 194-210, ago./dez. 2013".

SOUZA, Antonio C. M. Os tipos de povoamento. In: Os parceiros do Rio Bonito. São Paulo: Duas Cidades, 1987.

SOUZA, Anita S. Projeto Renascença: um caso de petrificação em Porto Alegre durante a década de 1970. Dissertação de Mestrado, UFRGS, 2008a.

SOUZA, Marcelo L. O território: sobre espaço e poder, autonomia e desenvolvimento. In: CASTRO, I; GOMES: C.; CORRÊA, R. (orgs.). Geografia: Conceitos e Temas. 11. ed. Rio de Janeiro: Bertrand Brasil: 15-47.2008b.

VEDANA, Viviane. "Fazer a Feira": estudo etnográfico das 'artes de fazer' de feirantes e fregueses da Feira Livre da Epatur no contexto da paisagem urbana de Porto Alegre. Dissertação de Mestrado. UFRGS, 2004.

ZAMBONI, Vanessa. Construção social do espaço, identidades e territórios em processo de remoção: o caso do bairro Restinga - Porto Alegre/RS. Dissertação de Mestrado. UFRGS, 2009.

Recebido em: 16/08/2017. Aprovado em: 15/11/2017. 